\title{
Neuronal Basic Helix-Loop-Helix Proteins (NEX and BETA2/Neuro D) Regulate Terminal Granule Cell Differentiation in the Hippocampus
}

\author{
Markus H. Schwab, ${ }^{1}$ Angelika Bartholomae, ${ }^{1}$ Bernd Heimrich, ${ }^{2}$ Dirk Feldmeyer, ${ }^{3}$ Silke Druffel-Augustin, ${ }^{1}$ \\ Sandra Goebbels, ${ }^{1}$ Frank J. Naya, ${ }^{4}$ Shanting Zhao, ${ }^{2}$ Michael Frotscher, ${ }^{2}$ Ming-Jer Tsai, ${ }^{4}$ and \\ Klaus-Armin Nave ${ }^{1}$

\begin{abstract}
1Zentrum für Molekulare Biologie, University of Heidelberg, D-69120 Heidelberg, Germany, ${ }^{2}$ Department of Anatomy, University of Freiburg, D-79001 Freiburg, Germany, ${ }^{3}$ Max-Planck-Institut für Medizinische Forschung, Abteilung Zellphysiologie, D-69120 Heidelberg, Germany, and 4Department of Cell Biology, Baylor College of Medicine, Houston,
\end{abstract} \\ Texas 77030
}

The transcription factors neuronal helix-loop-helix protein (NEX)/mammalian atonal homolog 2 (Math-2), BETA2/neuronal determination factor (NeuroD), and NeuroD-related factor (NDRF)/NeuroD2 comprise a family of Drosophila atonalrelated basic helix-loop-helix (bHLH) proteins with highly overlapping expression in the developing forebrain. The ability of BETA2/NeuroD and NDRF to convert ectodermal cells into neurons after mRNA injection into Xenopus oocytes suggested a role in specifying neuronal cell fate. However, neuronal bHLH genes are largely transcribed in CNS neurons, which are fully committed. Here we analyze a defect in mice lacking BETA2/ NeuroD, and in NEX ${ }^{\star} B E T A 2 / N e u r o D$ double mutants, demon-

Basic helix-loop-helix (bHLH) proteins are transcription factors involved in specifying and executing cell fate decisions in a variety of biological systems (Kageyama and Nakanishi, 1997; Arnold and Winter, 1998). In the mammalian nervous system, several gene products related to Drosophila atonal have been identified (Lee, 1997) and at least one subfamily, termed neurogenins, has been implicated in the determination of neuronal cell fate (Ma et al., 1996; Sommer et al., 1996). The normal function of another group of bHLH proteins (Bartholomae and Nave, 1994; Lee et al., 1995; Naya et al., 1995; Shimizu et al., 1995; Kume et al., 1996; McCormick et al., 1996; Yasunami et al., 1996), which includes neuronal helix-loop-helix protein (NEX)/mammalian atonal homolog-2 (Math-2), BETA2/neuronal determination factor (NeuroD), and NeuroD-related factor (NDRF)/NeuroD2, is less clear, however, because these genes are expressed throughout neuronal development and largely by committed cells outside the ventricular zone. Moreover, transcription is high in some

\footnotetext{
Received Dec. 23, 1999; revised Feb. 28, 2000; accepted March 6, 2000.

This work was supported by grants from the Deutsche Forschungsgemeinschaft (SFB229 and SFB505), Bundesministerium für Bildung und Forschung (Schwerpunkt Gentherapie), and the European Biomed-2 program to K.A.N. M.-J.T. acknowledges grant support from National Institutes of Health (HD17379 and DK55325). We thank H. Betz, K. Beyreuther, P. Gass, G. Schütz, J. Trotter, and B. Zalc for various antibodies and A. Berns for providing us with "floxed" Cre indicator mice. We also thank H. Krischke and F. Zimmermann for excellent technical assistance and M. Rossner for helpful discussions.

M. S. and A. B. contributed equally to this work.

Correspondence should be addressed to Dr. Klaus-Armin Nave, Department of Neurogenetics, Max-Planck-Institute for Experimental Medicine, Hermann-ReinStrasse 3, D-37075 Göttingen, Germany. E-mail: nave@sun0.urz.uni-heidelberg.de.

Dr. Schwab's present address: The Scripps Research Institute, Department of Neuropharmacology, 10550 North Torrey Pines Road, La Jolla, CA 92037.

Copyright (C) 2000 Society for Neuroscience $0270-6474 / 00 / 203714-11 \$ 15.00 / 0$
}

strating that bHLH proteins are required in vivo for terminal neuronal differentiation. Most strikingly, presumptive granule cells of the dentate gyrus are generated but fail to mature, lack normal sodium currents, and show little dendritic arborization. Long-term hippocampal slice cultures demonstrate secondary alterations of entorhinal and commissural/associational projections. The primary developmental arrest appears to be restricted to granule cells in which an autoregulatory system involving all three neuronal bHLH genes has failed.

Key words: dentate gyrus; granule cells; neuronal differentiation factors; basic helix-loop-helix proteins; Cre recombination; Cajal-Retzius cells areas of the adult CNS (Schwab et al., 1998). This suggested a role in differentiation, whereas initial gain-of-function experiments (involving overexpression in frog oocytes) demonstrated, by neurogenic conversion, that at least BETA2/NeuroD and NDRF/NeuroD2 can act as determination factors (Lee et al., 1995; McCormick et al., 1996). Given the uncertainty of abnormal timing in these and related experiments involving ectopic expression (Ahmad et al., 1998; Yan and Wang, 1998; Morrow et al., 1999), the normal function of neuronal bHLH proteins has remained unclear. Moreover, initial gene targeting experiments have revealed that BETA2/NeuroD is essential for pancreas development, and its loss of function is lethal, presumably because of early postnatal diabetic failure (Naya et al., 1997). An essential function of BETA2/NeuroD during pancreatic $\beta$-cell development is also supported by the finding that mutations in the human neuroD gene are associated with the development of type 2 diabetes mellitus (Malecki et al., 1999).

Recently, Lee and coworkers reported that pancreatic rescue of BETA2/NeuroD null mutants could be achieved with a NeuroDcDNA transgene when expressed under control of the rat insulin promoter (Miyata et al., 1999). A morphological defect of cerebellar and hippocampal development was also described. Here we report a more detailed analysis of granule cell differentiation in the hippocampus of mutant mice that lack both BETA2/NeuroD and NEX. This study includes the analysis of BETA2/NeuroD and NEX single mutants, in which neuronal bHLH proteins show at least a partial compensation when coexpressed (Schwab et al., 1998). We have used a long-term organotypic hippocampal culture system as an alternate means to overcome early lethality and to study the secondary effects of entorhinal and commissural/ 
associational projections. Moreover, electrophysiological recordings in acute slice preparations and dye fillings allowed us to monitor the neuronal differentiation defect at the single-cell level.

\section{MATERIALS AND METHODS}

$\beta 2 / N e u r o D$ and NEX mutant mice. The generation of BETA2/NeuroD $-/-$ and NEX $-/-$ mice has been described (Naya et al., 1997; Schwab et al., 1998). NEX-Cre mice were generated by a knock-in gene replacement strategy (S. Goebbels, M. Schwab, and K.-A. Nave, unpublished observations) that closely matched in outcome the NEX knockout mice of Schwab et al. (1998). Double heterozygous animals (NEX+/ -*BETA2/NeuroD+/-) and viable NEX-/-*BETA2/NeuroD+/mutants were used to generate offsprings of all genotypes analyzed. Mice were kept on a mixed 129Sv/C57B16 genetic background. For genotyping embryonic and newborn mice, genomic DNA was prepared from hindlimbs and tail tissue, respectively. PCR reactions using NEX-specific primers (NEX $250 \mathrm{sec}$, NEX1350as) and BETA2/NeuroD-specific primers (B2.1, B2.2, B2.lacZ) were performed as described (Naya et al., 1997; Schwab et al., 1998).

In situ hybridization. For in situ hybridization, embryos and brains were dissected without fixation, frozen on dry ice, and stored at $-70^{\circ} \mathrm{C}$. Sections of $15 \mu \mathrm{m}$ thickness were cut on a cryostat (model AS620M; Shandon) at $-15^{\circ} \mathrm{C}$, thaw-mounted onto poly-L-lysine-coated glass slides, dried at room temperature (RT), fixed in $4 \%$ PBS-buffered paraformaldehyde (PFA), $\mathrm{pH} 7.5$, for $5 \mathrm{~min}$, washed in PBS, dried at RT, and stored at $-70^{\circ} \mathrm{C}$. For in vitro transcription of cRNA probes, species-specific templates were generated by PCR amplification of genomic DNA and subcloning of the protein coding regions into vectors pKS (Stratagene, La Jolla, CA) or pGEM-T (Invitrogen, San Diego, CA). Sense and antisense RNA-probes were transcribed in vitro using T7, T3, or SP6 RNA-polymerase according to the manufacturer's instructions (Boehringer Mannheim, Mannheim, Germany). cRNA probes were subjected to partial alkaline hydrolysis to reduce probe size to 200-300 nucleotide fragments. Probes were diluted 1:100 in hybridization buffer and stored at $-20^{\circ} \mathrm{C}$. Prehybridization, hybridization, and immunological detection of digoxigenin-labeled cRNAs was performed as described (Schwab et al., 1998).

Histology and immunohistochemistry. Animals were killed by transcardiac perfusion under deep anesthesia (pentobarbital). After perfusion with $0.9 \% \mathrm{NaCl}$, brains were fixed in situ with $4 \%$ (w/v) PFA in PBS, pH 7.4. Brains were removed and post-fixed overnight in the same fixative, before vibratome sectioning. The brains of postnatal day 2 (P2) animals and younger were fixed in $4 \%$ PFA overnight without perfusion. After a brief rinse in PBS, they were transferred to $30 \%$ sucrose in PBS for cryoprotection (overnight), washed, frozen on dry ice, and stored at $-80^{\circ} \mathrm{C}$. Vibratome sections of $15-25 \mu \mathrm{m}$ were obtained with a Leica (Nussloch, Germany) VT1000s Vibratome and stored in PBS at $4^{\circ} \mathrm{C}$ for up to 2 weeks. Immunohistological analysis was performed on coronal free-floating vibratome sections $(15-25 \mu \mathrm{m})$, incubated with a panel of primary antibodies against neural marker proteins. Sections were permeabilized in $50 \mathrm{~mm}$ Tris-buffered saline (TBS) containing $0.4 \%$ Triton $\mathrm{X}-100$ for $30 \mathrm{~min}$ at room temperature and blocked in TBS containing $0.2 \%$ Triton-X100 and $4 \%$ horse serum (HS). Primary antibodies (see below) were diluted in TBS, $0.1 \%$ Triton $\mathrm{X}-100$, and $2 \% \mathrm{HS}$ at $4^{\circ} \mathrm{C}$ overnight. After washing with TBS, sections were incubated with a secondary antibody (see below) and diluted in TBS and $1.5 \% \mathrm{HS}$ for $2 \mathrm{hr}$ at room temperature or at $4^{\circ} \mathrm{C}$ overnight. After final washes in TBS, sections were mounted with AquaPolymount (Polysciences, Warrington, PA), imaged on a Leica DMRXA microscope, and photographed (Hamamatsu digital camera). Image processing was done with Openlab and Adobe Photoshop software.

For lacZ histochemistry, $10 \mu \mathrm{m}$ cryostat sections were fixed with $4 \%$ formaldehyde in PBS and washed. Slides were incubated in lacZ staining solution $\left(1.2 \mathrm{mg} / \mathrm{ml} \mathrm{X-Gal,} 2 \mathrm{mM} \mathrm{MgCl}_{2}, 5 \mathrm{mM} \mathrm{K}_{3} \mathrm{Fe}(\mathrm{CN})_{6}\right.$, and $5 \mathrm{~mm}$ $\mathrm{K}_{4} \mathrm{Fe}(\mathrm{CN})_{6}$ in $\left.\mathrm{PBS}\right)$ at $37^{\circ} \mathrm{C}$ for $3-4 \mathrm{hr}$ in a $5 \% \mathrm{CO}_{2}$ atmosphere, washed three times at RT in PBS and once in water for $10 \mathrm{~min}$, counterstained 4',6'-diamidino-2-phenylindole (DAPI) $(0.5 \mu \mathrm{g} / \mathrm{ml})$, washed, and embedded in Kaiser's glycerol gelatin.

Antisera were kindly provided by H. Betz (synaptoporin; diluted 1:200), K. Beyreuther [amyloid precursor protein (APP); 1:250], P. Gass (calretinin, 1:2000), G. Schütz (recombinase Cre; 1:8000), B. Zalc (Hu antigen, 1:500), and monoclonal antibodies from J. Trotter (L1 and $\mathrm{N}-\mathrm{CAM}, 1: 20$ ). The neuronal $\mathrm{Hu}$ antigen has been described (Barami et al., 1995). Additionally, we used commercial monoclonal antibodies against microtubule-associated protein-2 (MAP-2) (Boehringer Mannheim; 1:400), synaptophysin (Boehringer Mannheim; 1:10), NeuN (Chemicon, Temecula, CA; 1:200), neurofilament 68 (NF-68) (Sigma, St. Louis, MO; 1:400), growth-associated protein-43 (Sigma; 1:200), MIB-5 (Dianova, Hamburg, Germany; 1:10; on cryostat sections), and rabbit antisera against glutamic acid decarboxylase (GAD-67) (Chemicon; 1:1000) and neuron-specific enolase (NSE) (Chemicon; 1:300). Secondary $\mathrm{IgG}$ antibodies were from Dianova (goat anti-rabbit and mouse) and were Cy3-conjugated (1:1000), Cy2-conjugated (1:200), or 5-(4,6dichlorotriazinyl)aminofluorescein-conjugated (1:200). Nuclei were stained with DAPI $(0.5 \mu \mathrm{g} / \mathrm{ml})$ or Hoechst (Hoechst, Frankfurt, Germany) $(10 \mu \mathrm{g} / \mathrm{ml})$ for $5 \mathrm{~min}$.

Terminal deoxynucleotidyl transferase-mediated biotinylated dUTP nick end labeling staining. Terminal deoxynucleotidyl transferase-mediated biotinylated dUTP nick end labeling (TUNEL) staining of cryostat sections was performed with the in situ cell death detection kit (POD; Roche Molecular Biochemicals), according to the manufacturer's instruction.

Single-cell electrophysiological recording and biocytin filling. Wild-type and mutant mice (P2) were decapitated, and brains were dissected. Coronal slices $(400 \mu \mathrm{m})$ were cut in cold extracellular solution with a vibrating microslicer (DTK-1000; Dosaka, Kyoto, Japan). Slices were incubated at $35^{\circ} \mathrm{C}$ for $30 \mathrm{~min}$ and subsequently maintained at $20-23^{\circ} \mathrm{C}$. The extracellular solution contained (in $\mathrm{mM}$ ): $125 \mathrm{NaCl}, 2.5 \mathrm{KCl}, 25$ glucose, $25 \mathrm{NaHCO}_{3}, 1.25 \mathrm{NaH}_{2} \mathrm{PO}_{4}, 2 \mathrm{CaCl}_{2}$, and $1 \mathrm{MgCl}_{2}$ bubbled with $95 \% \quad \mathrm{O}_{2}$ and $5 \% \quad \mathrm{CO}_{2}$. Whole-cell recordings were made from hippocampal neurons under infrared-differential interference contrast optics, using patch electrodes filled with an intracellular solution containing (in $\mathrm{mM}$ ): $105 \mathrm{~K}$-gluconate, $30 \mathrm{KCl}, 10 \mathrm{HEPES}, 10$ phosphocreatine, 4 ATP-Mg, and 0.3 GTP, pH 7.3, $300 \mathrm{mOsm}$. Membrane currents were measured under voltage-clamp control and amplified using an EPC9 (Heka Elektronik, Lambrecht, Germany). Recordings were filtered at 3 $\mathrm{kHz}$, digitized at $5-10 \mathrm{kHz}$, and stored on a Macintosh computer for further analysis. For morphological analysis of patched cells, $2 \mathrm{mg} / \mathrm{ml}$ biocytin (Sigma) was added to the intracellular solution. To avoid destruction of the small presumptive neurons of the dentate gyrus, electrodes with a small tip diameter $(6-10 \mathrm{M} \Omega)$ were used. This may have compromised voltage-clamp recordings; these problems were probably minor, however, because the morphology of immature neurons is relatively compact. After 10-20 min of recording and biocytin filling, slices were fixed for at least $24 \mathrm{hr}$ at $4^{\circ} \mathrm{C}$ in $100 \mathrm{~mm}$ PBS, pH 7.4, containing $1 \%$ PFA and $2.5 \%$ glutaraldehyde. Slices were then processed according to the protocol by Horikawa and Armstrong, (1988), with minor modifications. After incubation in avidin-biotinylated horseradish peroxidase (ABC-Elite; Camon, Wiesbaden, Germany) slices were reacted under visual control using 3,3-diaminobenzidine until dendrites and axonal arbors were clearly visible (2-4 min). After post-fixation in $0.01 \% \mathrm{OsO} 4$, slices were mounted on microscopic slides and embedded in Mowiol (Hoechst). Biocytin-labeled neurons were examined by light microscopy $(400-1000 \times)$ and photographed; selected neurons were reconstructed using the Neurolucida system (Microbrightfield, Colchester, VT).

Organotypic slice culture. Single hippocampal slice cultures and complex slice cultures of entorhinal cortex and the adjacent hippocampus were prepared from newborn mice. Three hundred-micrometer-thick slices were cultivated on membranes for up to $14 \mathrm{~d}$ as described (Stoppini et al., 1991; Frotscher et al., 1995). For anterograde biocytin tracing, only slice cultures of at least $10 \mathrm{~d}$ in vitro (DIV) were used. One set of experiments was performed to label dentate granule cells with their mossy fiber axons. Under visual control, small crystals of biocytin were placed onto the presumptive dentate gyrus (DG) (from double mutant mice) or on the delineated granule cell layer (from wild-type littermates). After further incubation of the cultures to allow transport of the tracer $(36-48 \mathrm{hr})$, they were fixed for $2 \mathrm{hr}$ in a solution containing 4\% PFA, $0.1 \%$ glutaraldehyde, and saturated picric acid. After several rinses, cultures were resliced on a vibratome $(50 \mu \mathrm{m})$, and sections were immunostained overnight (ABC-elite 1:50; Vector Laboratories, Burlingame, CA). Subsequent DAB reaction was heavy metal-intensified as described (Adams, 1981; Deller et al., 1999). Sections were counterstained (cresyl violet), dehydrated, and coverslipped. For each genotype some cocultures were used for a combined labeling of entorhinal afferents and reelin-containing neurons (Cajal-Retzius cells) in the target area. To label the entorhinohippocampal pathway, crystals of biocytin were placed onto the superficial layers of the entorhinal cortex. The tissue was further processed as described above. Sections that showed a distinct, blackcolored entorhinal projection to the hippocampal part of the cocultures 
A

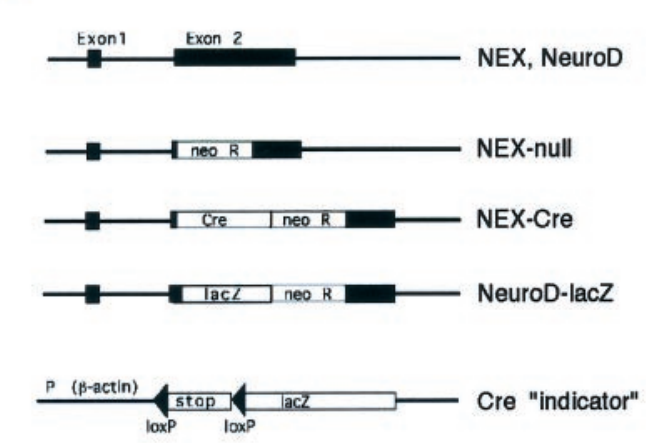

B
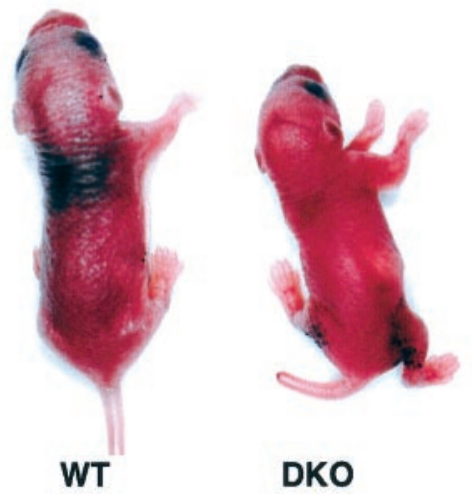

DKO
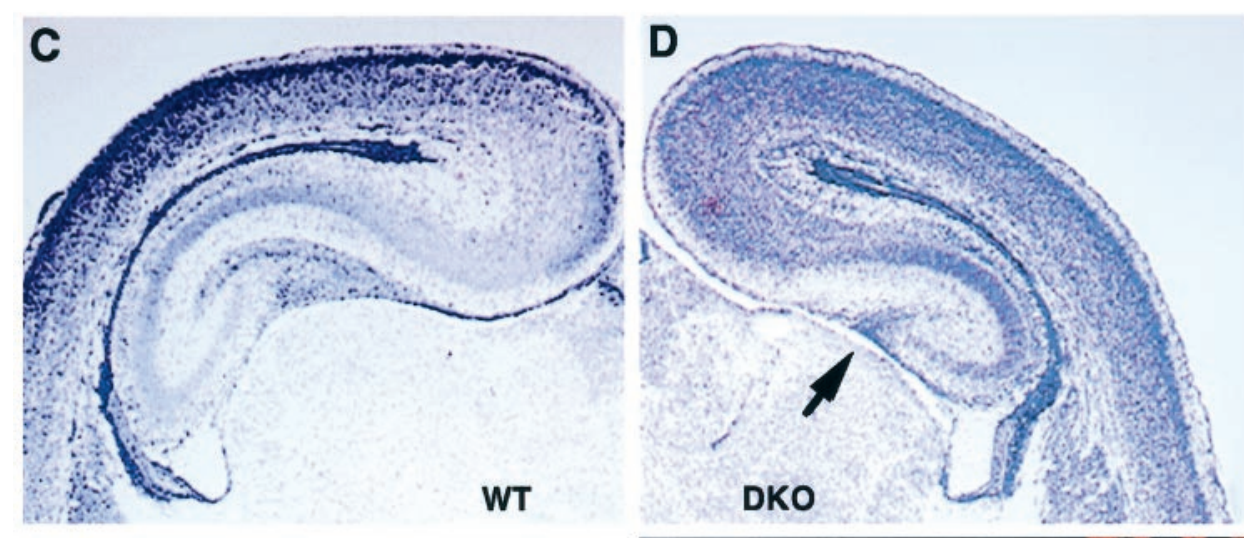

\section{E}

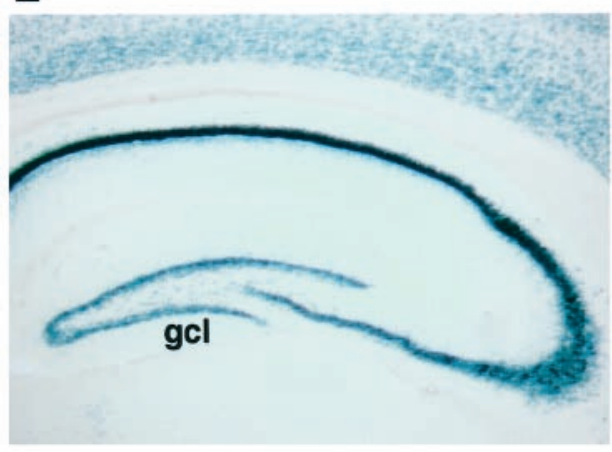

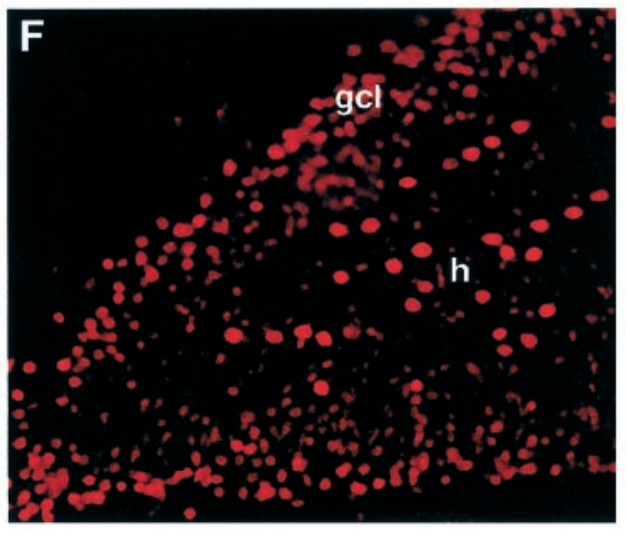

Figure 1. A, Schematic organization of normal and targeted gene loci. In all neuronal bHLH genes, exon 2 contains the coding region, most of which has been replaced in NEX null mice by neo (Schwab et al., 1998). In BETA2/NeuroD knock-out mice, the lacZ gene is fused to the $5^{\prime}$ part of exon 2 of the BETA2/NeuroD gene, and thus is under control of the endogenous promoter (Naya et al., 1997). In a second line of NEX-deficient mice, the recombinase Cre gene is placed under control of the endogenous NEX promoter (NEX-Cre; Goebbels, Schwab, and Nave, unpublished observations). A floxed lacZ-transgene, driven by the $\beta$-actin promoter, defines the line of "Cre indicator" mice (Akagi et al., 1997). When bred to NEX-Cre mice, removal of the "floxed" stop cassette in double transgenics activates permanent lacZ expression. $B$, NEX*BETA2/NeuroD double mutants die a few days after birth. Depicted are two siblings at P2. The double mutant (right) displays obvious developmental delays compared to the double heterozygous (left). This growth retardation was seen in all BETA2/NeuroD mutants independent of the NEX gene. $C, D$, Nissl staining of a coronal section from a normally developed mouse brain $(C)$ and a NEX*BETA2/NeuroD double mutant $(D)$ at $\mathrm{P} 2$. Overall brain organization and neocortical structures appear intact, but the dentate gyrus is absent from the hippocampal formation $(D$, arrow). $E, F$, Transient NEX expression in normal DG neurons. $E$, Coronal brain section of a NEX-Cre*indicator doubletransgenic mouse at P55. Mature dentate GCs are stably marked by lacZ histochemistry, demonstrating that the NEX gene is transcribed, at least transiently, also in cells of the GC lineage. By in situ hybridization, adult GC lack NEX mRNA (Bartholomae et al., 1994; Schwab et al., 1998). F, Immunodetection of Cre in dentate GC at P2 using a Cre-specific antibody. were selected for reelin immunocytochemistry. These slices were incubated overnight with the antibody G10 (a monoclonal anti-reelin antibody raised in mouse; dilution, 1:1000; kindly provided by Dr. Goffinet, Namur, Belgium). Biotinylated anti-mouse secondary antibody (dilution 1:200) was used for $12 \mathrm{hr}$. After several rinses in PBS, ABC elite (1:100; Vector Laboratories) was administered overnight, followed by a DAB reaction that yielded a brown color of immunopositive reelin-containing neurons.

Calretinin immunofluorescence was used to visualize hilar mossy cells and their axonal projection to the inner molecular layer of the dentate gyrus. Briefly, after 10-14 DIV, cultures were fixed in 4\% PFA (2 hr), vibratome-sectioned $(50 \mu \mathrm{m})$, and incubated with $5 \%$ normal goat blocking solution (30 min) before applying the calretinin antibody (Swant, Bellinzona, Switzerland) diluted 1:3000 in $0.1 \mathrm{M}$ PBS $\left(4^{\circ} \mathrm{C}\right.$, overnight). Secondary antibody (Cy3-conjugated anti-rabbit IgG; $1: 1000$ ) was administered for $4 \mathrm{hr}$. After thoroughly rinsing, sections were mounted onto slides with Moviol (Hoechst), coverslipped, and examined under epifluorescence with a TRITC filter set.

For Timm staining of hippocampal mossy fibers, slice cultures were immersed in $1.2 \%$ sodium sulfide $(20 \mathrm{~min})$, followed by a fixative containing $2.5 \%$ glutaraldehyde in PBS (20 min), and post-fixed in $70 \%$ ethanol $(21 \mathrm{hr})$. After cryoprotection, horizontal frozen sections $(40 \mu \mathrm{m})$ were cut, mounted onto gelatin-coated slides, and Timm-stained as described (Schwegler et al., 1988). Sections were counterstained with cresyl violet before embedding.

\section{RESULTS}

BETA2/NeuroD-/- mutant mice die between P3 and P5 (Naya et al., 1997), whereas NEX-/- mutants have a normal lifespan (Schwab et al., 1998). In contrast, NEX-/- BETA2/Neuro D $-/-$ double mutant mice were born at the expected Mendelian frequency, but rarely survived P2. This difference was in line with a possible compensation between neuronal bHLH proteins. We therefore compared all genotypes, including single and double mutants, side by side. The present report focuses on $\mathrm{NEX}-/-^{*}$ BETA2/NeuroD-/- double mutants, which displayed a more uniform loss-of-function phenotype than the BETA2/NeuroD single mutant.

To monitor the transcriptional activity of the targeted genes, we used "knock-in" strategies that created reporter gene fusions 

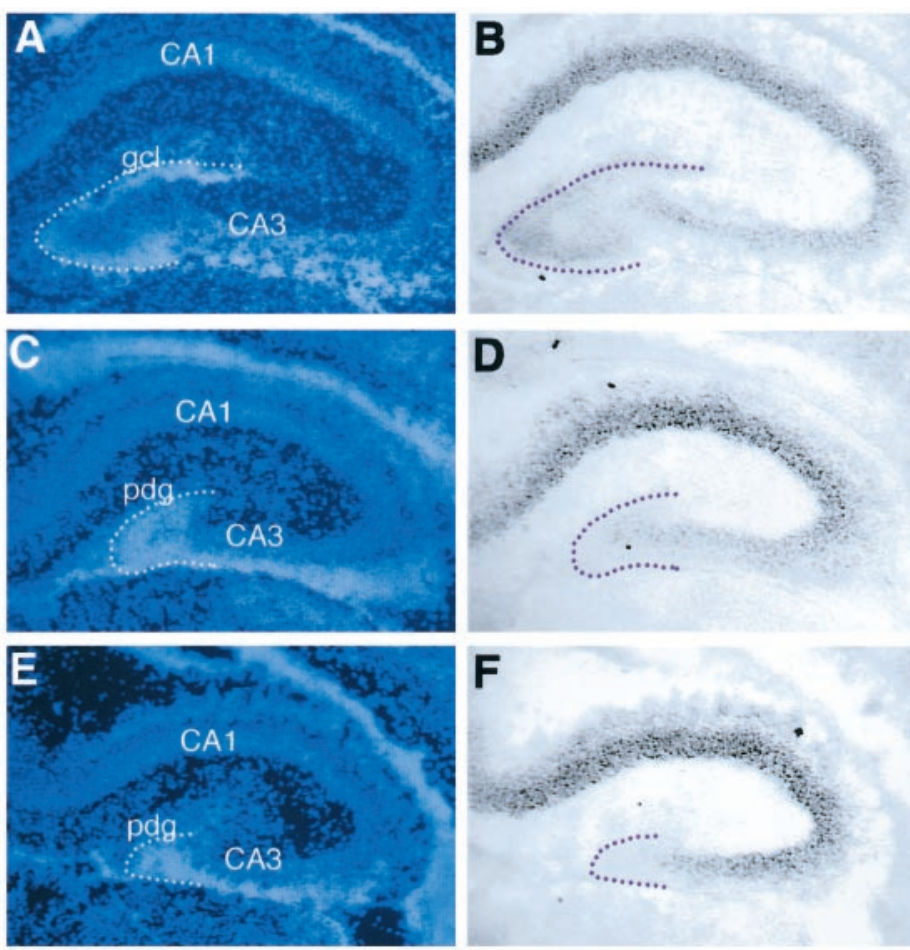

Hoechst

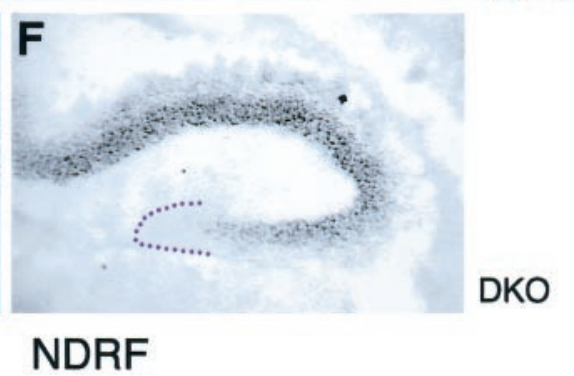

WT

Figure 2. Transcription of bHLH genes and loss of positive autoregulation. Nuclear labeling with Hoechst dye of the developing hippocampus of wild-type mice $(A)$, BETA2/ NeuroD single mutants $(C)$, and NEX $-/-{ }^{*}$ BETA2/Neuro $\mathrm{D}-/-$ double mutants $(E)$. Note that the absence of NEX further reduces the overall hippocampal size and the number of cells in the pdg. Pyramidal neurons of the CA1-3 fields appear unaffected in either mutant. By in situ hybridization for NDRF, the developing DG of normal mice is clearly labeled $(B)$. In single and double mutants, cells of the prospective DG show very little or no NDRF expression $(D, F)$. Transcription of the NDRF gene in CA1-3 pyramidal neurons is not affected.
(Fig. 1A). In NEX-Cre mice (a null mutant allele), the recombinase Cre gene is under control of the endogenous full-length NEX promotor, and Cre was detected indirectly (lacZ) after breeding with a strain of floxed "indicator" mice (Akagi et al., 1997) or immunocytochemically (Fig. $1 E, F$ ). In BETA2/NeuroD mutant mice, the endogenous promotor was driving expression of the lacZ gene (Naya et al., 1997).

By gross inspection, CNS development of double mutants did not differ from that of either parental single mutant or from wild-type controls, but brain size was noticeably reduced in the absence of BETA2/NeuroD, as was overall growth (Fig. 1B). Moreover, microscopic examination revealed histological differences between controls and double mutants (Fig. 1C,D), which were apparent to a slightly reduced degree also in BETA2/ NeuroD $-/-$ single mutants. Most obvious and consistent was the hippocampal abnormality with the apparent lack of a DG. Because of its well known cytoarchitecture, the hippocampus was chosen for a more detailed analysis.

In rodent development, formation of the hippocampal DG begins at $\sim$ E16. The primary dentate neuroepithelium (DG anlage) differs from the adjacent ventricular zone of the CA3 field in that it gives rise to migratory neurons that form a secondary germinal matrix. This secondary matrix continues to produce proliferative cells, and after migration, a tertiary matrix in the hilar region. Terminal migration and differentiation results in a V-shaped layer of positioned neurons, most of which are granule cells (GC) (Stanfield and Cowan, 1979; Altman and Bayer, $1990 a, b)$. Some progenitors remain proliferative, giving rise to new granule cells throughout postnatal development. In BETA2/ NeuroD-deficient mice, routine staining of the hippocampus at age P0 or P2 consistently revealed the lack of a demarcated GC layer $(\mathrm{gcl})$, and instead an ectopic aggregate of cells within the hilar region (Fig. 2A,C,E). Based on the specific location and temporal emergence, most of these cells are presumptive DG (pdg) neurons that failed to migrate to their final position in the DG itself. This defect appeared more pronounced in BETA2/ NeuroD $-/-* \mathrm{NEX}-/-$ double mutants [double knock-out (DKO)] than in BETA2/NeuroD-/- single mutants. Difficult to quantify but most consistent, the number of lacZ-stained cells in the hilar region (see below) and of migratory granule cell precursors (on their way to the hilar region) was more reduced in double mutants than in single mutants. Although plausible, this additive effect of two mutations appeared to contradict our previous observation that neuroD mRNA, but not NEX mRNA, was expressed by mature DG granule cells (Bartholomae et al., 1994; Schwab et al., 1998).

We therefore reinvestigated the possibility of a transient NEX expression in GC or their progenitors, using the highly sensitive, Cre-mediated activation of a "floxed" $\beta$-actin-lacZ-reporter gene in double-transgenic NEX-Cre mice (Fig. $1 E$ ). In these experiments we found that granule cells of the DG were stably marked $(\mathrm{lacZ}+)$ and therefore derived from NEX-expressing immature neurons or progenitors. The transient nature of NEX expression was confirmed by immunohistochemical staining of Cre itself at P2 (Fig. $1 F$ ), a pattern that was lost from the DG of adult NEX-Cre mice (data not shown). A weak expression of NEX/ MATH2 in the developing DG has been reported by Shimizu et al. (1995). Thus, DG neurons express all three neuronal bHLH proteins at some point in development, and the developmental defect is most pronounced in DKO mice. The latter was supported by direct cell counts: in sections of the affected hilar region from DKO mice and BETA2/NeuroD single mutants, we counted $707 \pm$ and 1081 \pm DAPI-stained nuclei, respectively (10 and 12 sections of each genotype). Thus, the total number of hilar cells was $\sim 30 \%$ lower in DKO than in BETA2/NeuroD single mutants.

Utilizing the lacZ reporter function of the targeted BETA2/ NeuroD gene, the lack of a normal GC layer was obvious. 


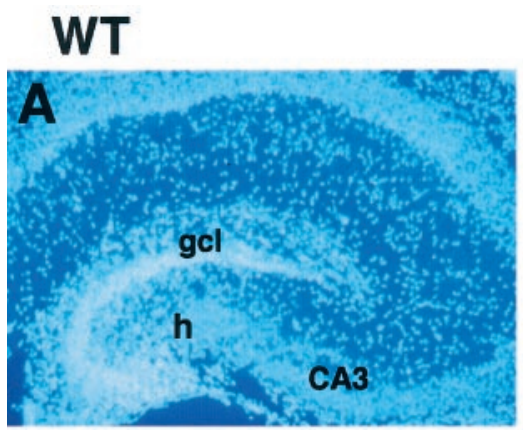

\section{DKO}
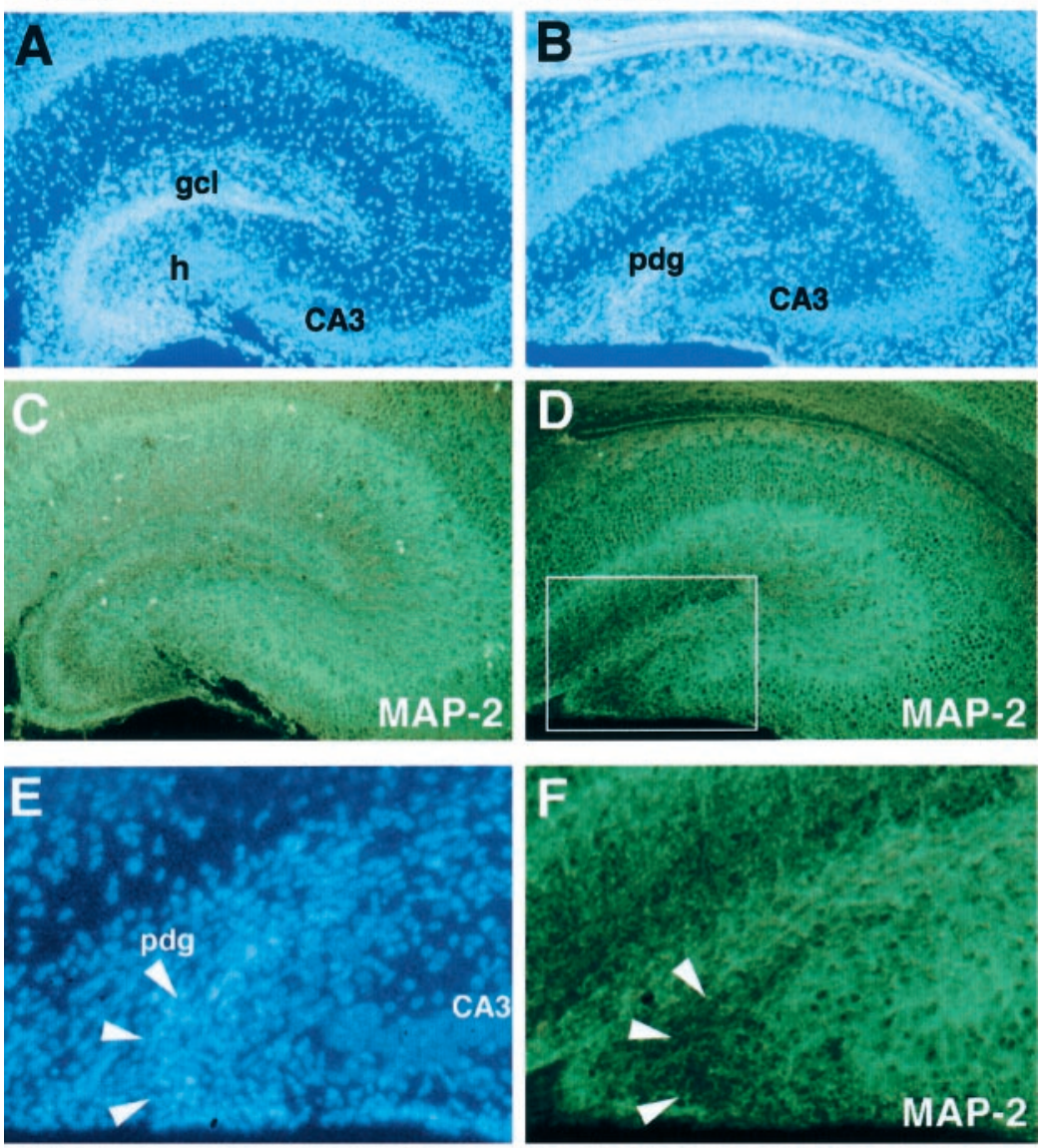

Figure 3. Arrest of terminal neuronal differentiation in the developing dentate gyrus. When analyzed by nuclear DAPI staining at $\mathrm{P} 2$, wild-type mice $(A)$ displayed a differentiated granule cell layer $(\mathrm{gcl})$, separated from the hilus $(H)$ and CA3 field. In BETA2/NeuroD*NEX double mutants $(B)$, cells of the pdg are reduced in number and poorly organized. In the BETA2/NeuroD*NEX double mutant $(D-F)$, these cells also lack normal expression levels of terminal differentiation markers, such as the dendritic protein MAP-2, whereas in the wild-type $(C)$ cells of the gcl clearly express MAP-2. The boxed area in $D$, when enlarged $(E, F)$, shows a cluster of DAPI-stained nuclei $(E, p d g)$ that is barely associated with MAP-2 immunoreactivity $(F$, arrowheads). In other sections $(G-J)$, however, mutant cells are clearly stained with antibodies against the neuronal Hu-antigen $(G, H)$ or NSE $(I, J)$, demonstrating early but not late neuronal differentiation. Results of BETA2/NeuroD single mutants were comparable, except that more cells in the hilar region expressed differentiation markers.
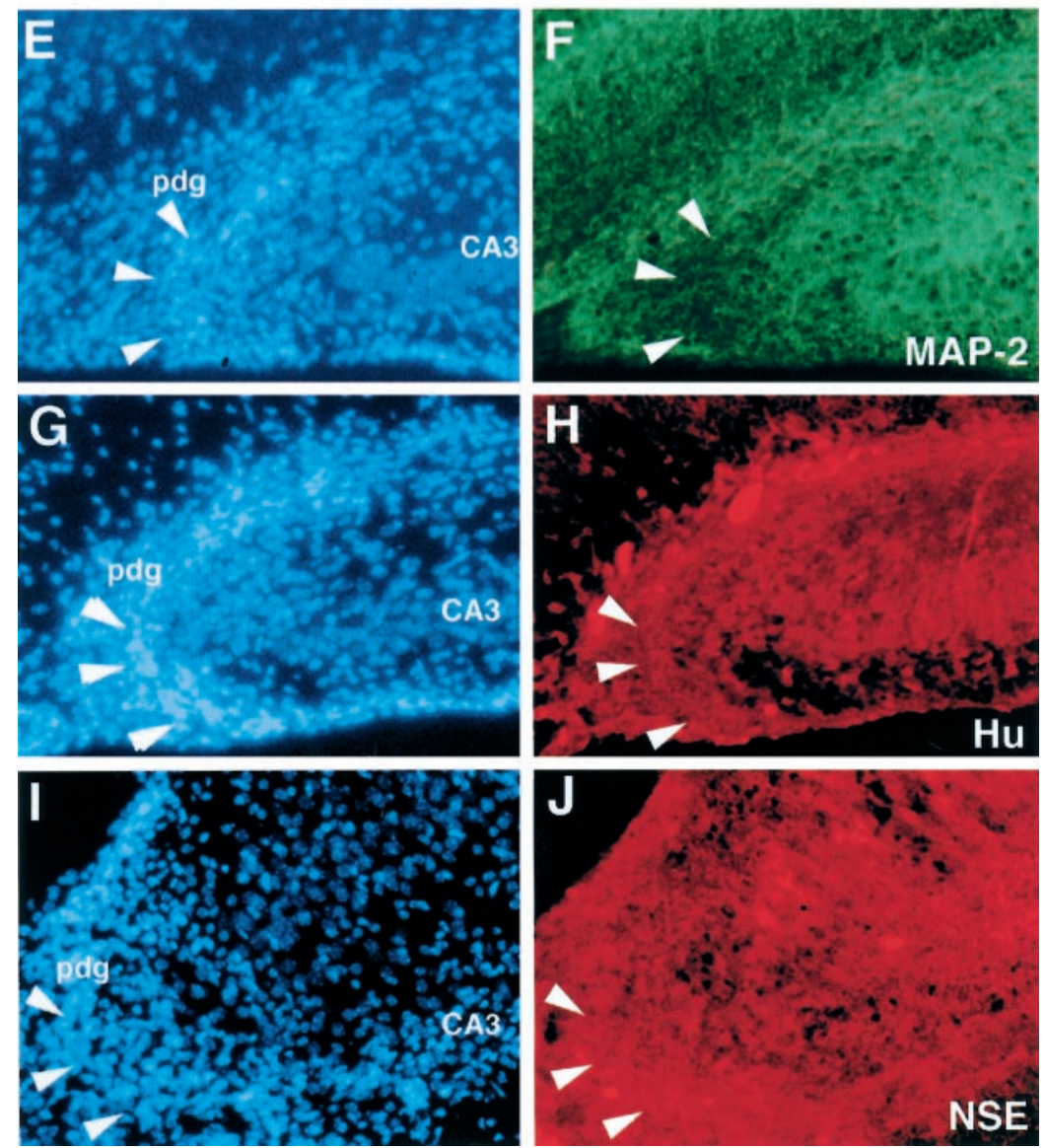

BETA2/NeuroD promoter activity was detectable but weak in the hilar region of the mutants, suggesting that a positive transcriptional autoregulation may be affected. Such an autoregulation has been described for the family of muscle bHLH proteins (Thayer et al., 1989) and is supported in the neuronal bHLH system by direct activation of the NEX promoter and the BETA2/NeuroD promoter in transfected cells (Bartholomae and Nave, 1994; McCormick et al., 1996; Yoon et al., 1998). We suggest that auto- regulation may also include, at the transcriptional level, the third family member, NDRF/NeuroD2, which is normally coexpressed by DG granule cells (McCormick et al., 1996; Schwab et al., 1998). By in situ hybridization (Fig. 2), the cells of the hilar region in mutants, including the prospective granule cells, remain NDRFnegative. This effect appears slightly more pronounced in the NEX*NeuroD double mutant (Fig. $2 F$ ) than in a single mutant (Fig. 2D). These cells also lack any detectable NEX transcripts 
TUNEL
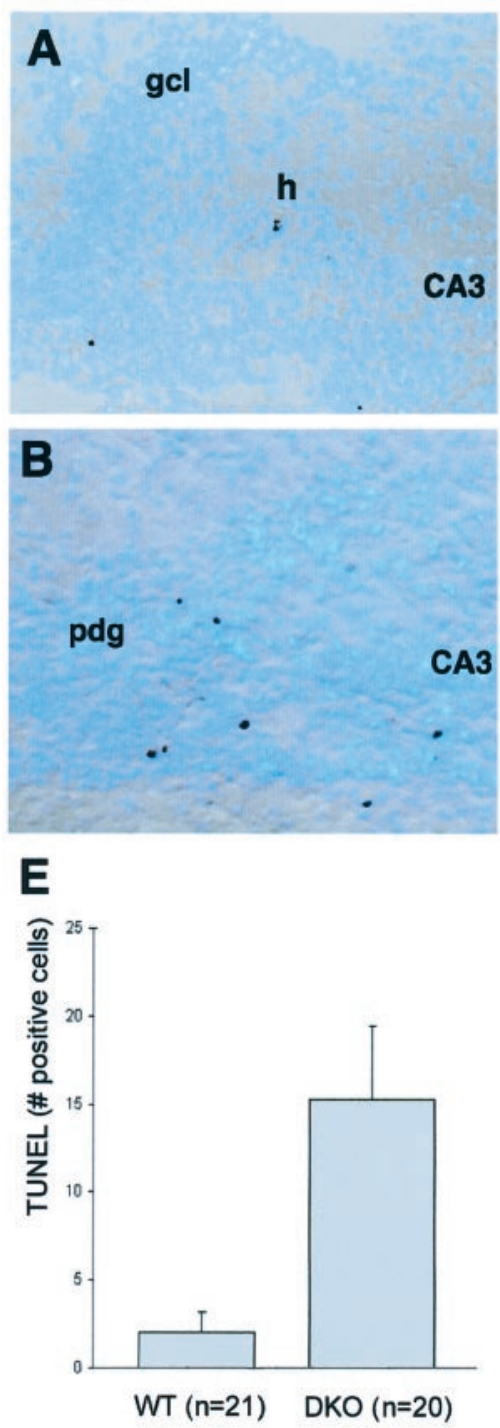

MIB-5
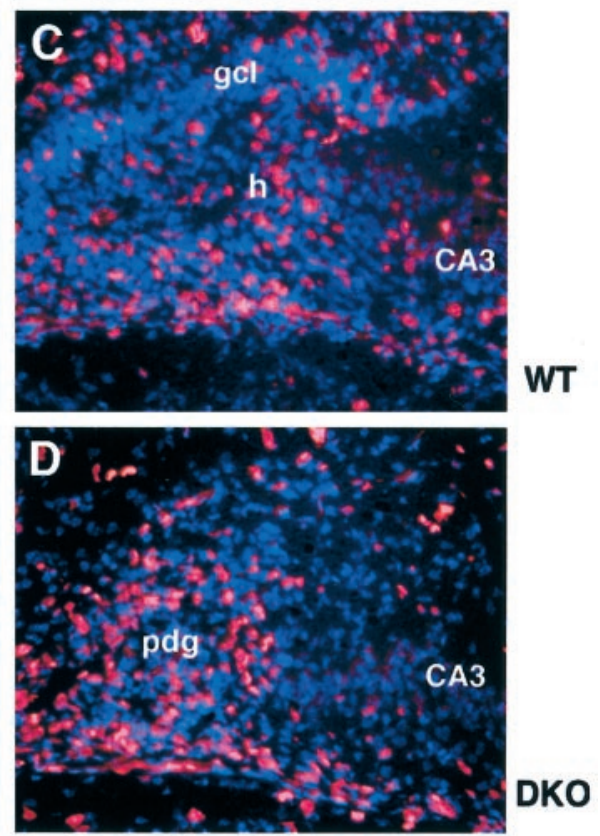

$\mathbf{F}$

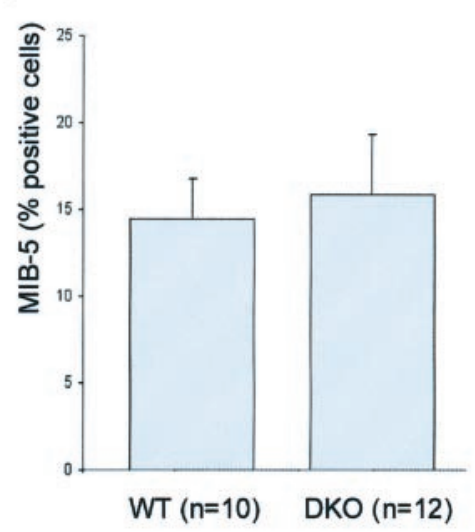

Figure 4. Apoptotic cell death and cell proliferation in the developing dentate gyrus at P2. By TUNEL staining, the number of labeled cells in cross-sections of the pdg is larger in double mutants $(B)$ than in the developing DG of wild-type controls $(A)$, indicating an increased rate of apoptosis for immature granule cells. The number of mitotic cells in this region, obtained by staining with MIB-5 antibody against the Ki-67 proliferation antigen, is similar in cross-sections of double mutants $(D)$ and wild-type controls $(C)$. E, TUNEL staining was from 20 double-mutant and 21 control sections (4 animals each), and differences were significant. when using a neospecific riboprobe (data not shown). Thus, loss of positive autoregulation and a local "triple knock-out" situation may contribute to a rather specific arrest of granule cell development. We emphasize that all mutant brains appeared morphologically normal at younger ages (E14-E16) and without defect of the hippocampal neuroepithelium. Transcription of the genes for neurogenin-2, NDRF, and NEX was not visibly affected at this time (data not shown).

The absence of a recognizable DG and the presence of a cap of ectopic cells in the hilar region suggests a principle differentiation arrest of hippocampal granule cells. At P2, immunohistochemical staining demonstrated that in the majority of affected cells a number of neuronal differentiation markers were not or only poorly expressed, including MAP-2 (Figs. 3C,D,F) and neurofilament NF-68 (data not shown). Other markers, including NSE and $\mathrm{Hu}$ antigen (Fig. 3G-J), APP, synaptoporin, and NeuN (data not shown) were clearly detectable, indicating that a partial neuronal differentiation has taken place. Unfortunately, known GCspecific markers are not yet expressed at P2. Occasional GAD-67 and calretinin staining was most likely interneuronal. Using monoclonal antibody MIB-5 against Ki-67 as a marker of prolif- erating cells (Gerlach et al., 1997), the number of stained cells among presumptive DG cells was not significantly increased (Fig. $4 C, D)$. However, more nuclei in the mutants than in controls were captured by TUNEL staining, indicating that many immature neurons die by apoptosis (Fig. 4A,B). The analysis of 21 wild-type and 20 double mutant hippocampal sections (from four animals each) revealed 7.5-fold as many TUNEL-stained cells in the hilar region of the DKO as compared to the wild type. Taken together, DG neurons are derived normally from a progenitor pool in the DG anlage, but arrest during terminal differentiation in the hilar region and are likely to degenerate.

To assess the hippocampal defect at the cellular level, we performed whole-cell patch-clamp recordings and biocytin fillings of presumptive GC, side-by-side, in both single and double mutants. For comparison, we recorded from CA3 pyramidal cells, hilar, and DG interneurons, which were unaffected in wild-type brains. The identification of GC was easier in the wild-type than in mutants because of the presence of a macroscopically visible DG. In the affected hilar region of BETA2/NeuroD single and double mutants, only the small aggregates of presumptive GC were found that differed in size (see above). Interspersed were 
A

B

Figure 5. Biocytin labeling of single cells and whole-cell patch-clamp analysis in acute slices of the dentate gyrus. $A$, Reconstruction after electrical recording of a differentiated GC in the wild-type DG $(a)$ and a typical immature GC in the hilar region of a NEX $-/-{ }^{*} \mathrm{BETA} 2 / \mathrm{NeuroD}-/-$ mutant $(b)$. For comparison, a double-mutant hilar interneuron $(c)$ and double-mutant cell of the CA3 field $(d)$ are shown that have developed normally. Arrows mark the axons, but presumptive $\mathrm{GC}$ in the NEX-/-*BETA2/NeuroD-/- lack clear axonal projections. $B$, Firing patterns of pyramidal cells $(C A 3$, top $)$ and dentate $\mathrm{GC}(D G$, bottom $)$ recorded in wild-type (WT, left $)$ and $\mathrm{NEX}-/-{ }^{*} \mathrm{BETA} 2 / \mathrm{NeuroD}-/-$ mice $(D K O$, right $)$. The membrane potential was set to $-60 \mathrm{mV}$ before action potentials were elicited by injection of $1 \mathrm{sec}$ current pulses. Note that CA3 pyramidal cells of either genotype could fire regenerative action potentials with peak amplitudes of $70-100 \mathrm{mV}$. In differentiated GC, only nonregenerative action potentials (amplitude, $60 \mathrm{mV}$ ) could be elicited. Presumptive GC in NEX -/ - *BETA2/NeuroD-/- mice never showed action potentials. Only a small current deflection on top the voltage response was observed (arrow). Firing patterns and current responses $(C)$ are from the same neurons. $C$, Current responses of CA3 pyramidal cells (top) and dentate GC (bottom) in slices from wild-type (left) and NEX-/-*BETA2/Neuro $\mathrm{D}-/-$ mice $(r i g h t)$. The membrane potential was held at -70 $\mathrm{mV}$, and $10 \mathrm{mV}$ voltage steps up to $+100 \mathrm{mV}$ were applied. Peak $\mathrm{Na}^{+}$current generally exceeded $1 \mathrm{nA}$ in CA3 pyramidal cells, but was smaller in DG granule cells. Presumptive GC in NEX $-/-{ }^{*}$ BETA2/NeuroD- - mutants had peak $\mathrm{Na}^{+}$currents $<500 \mathrm{pA}$ (arrow).

other neurons which, based on their firing pattern, morphology, and calretinin staining (see below), were identified as interneurons. In the wild type, differentiating DG granule cells had a typical bipolar appearance with axons projecting into the CA3 region and short dendrites pointing toward the molecular layer (Fig. 5Aa). At P2, there was a clear gradient of development, with GC that had migrated furthest also being the most advanced in morphology. In general, there was no obvious qualitative differ- a

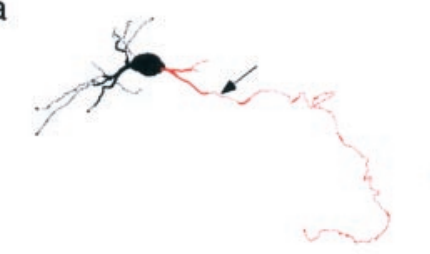

C
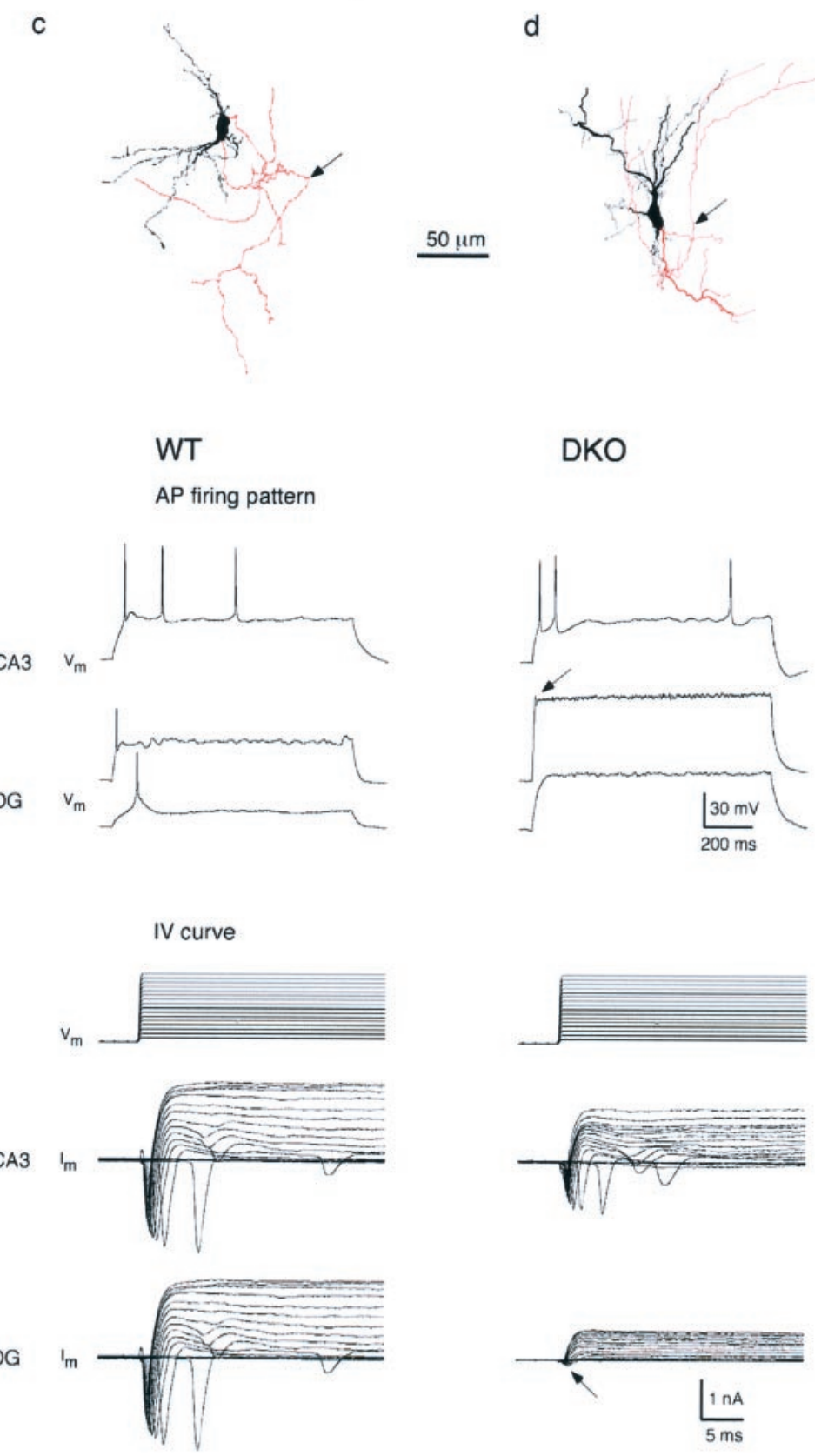

b
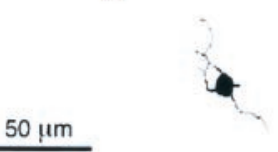

DKO
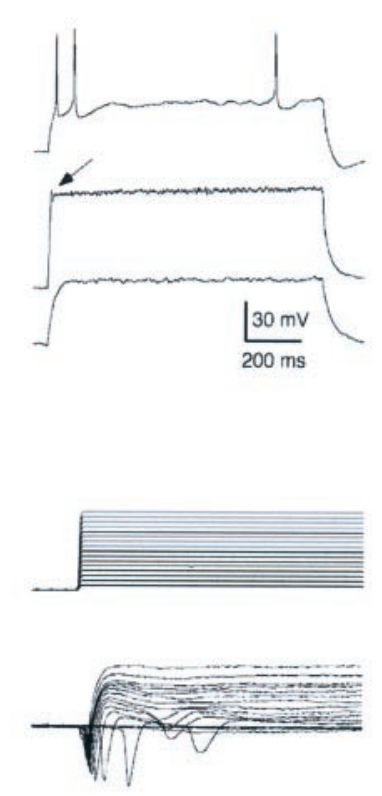

ence between individual immature GC from BETA2/Neuro $\mathrm{D}-/-$ mice and from NEX-/-*BETA2/NeuroD-/- double mutants. However, a quantitation was difficult as cells were sampled for recording always from the most advanced region of the presumptive DG. After biocytin filling, presumptive GC never revealed axons that extended to the CA3 layer; but some had short dendrites (Fig. 5Ab). In contrast, CA3 pyramidal cells, hilar neurons, and DG interneurons appeared equally differentiated in 

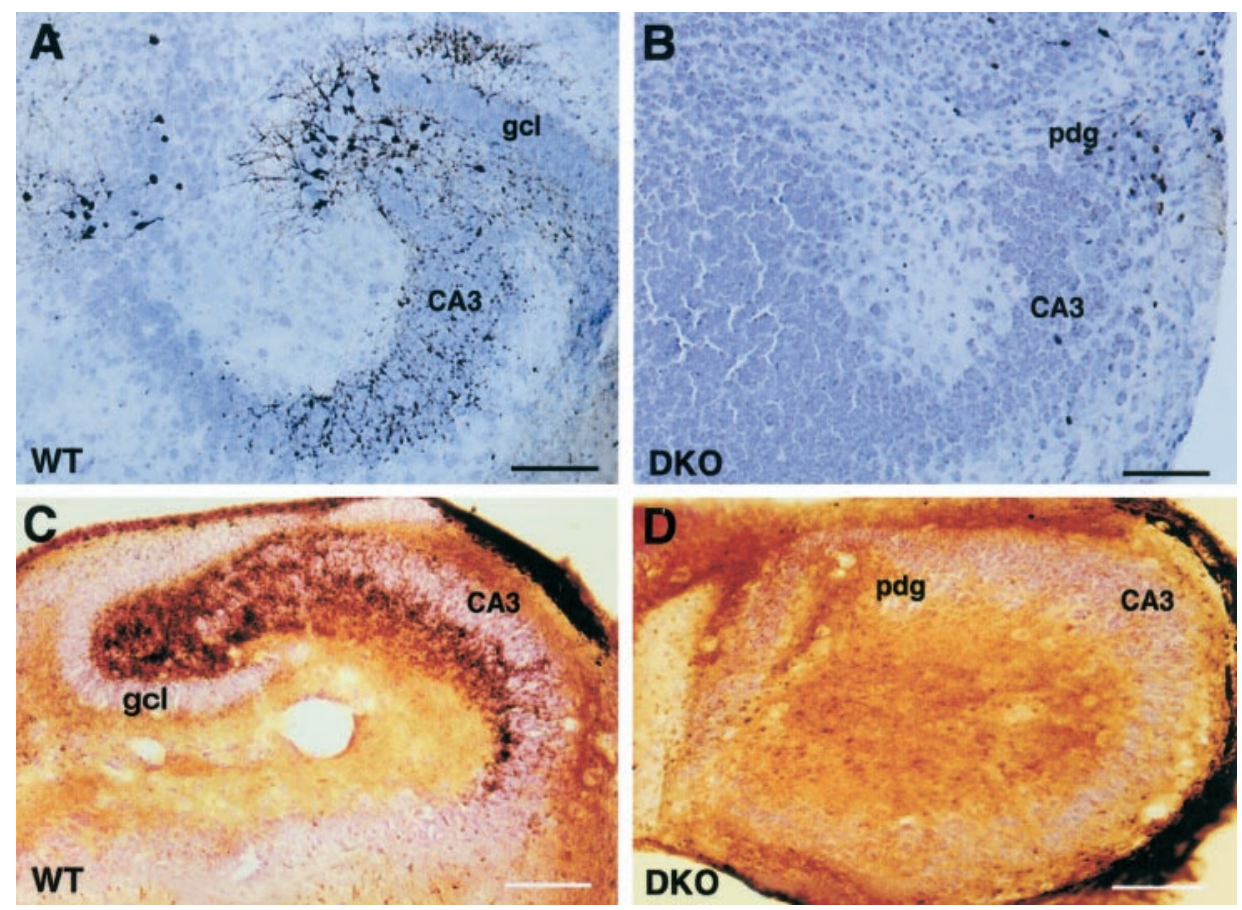

Figure 6. Long-term slice cultures of hippocampi from newborn wild-type mice and double mutants. $A$, The dentate granule cell layer $(g c l)$ has developed in a slice culture derived from a wild-type mouse after 10 DIV. After application of the anterogradely transported tracer biocytin, numerous labeled GC with apical dendrites extending into the molecular layer as well as a mossy fiber projection to the hippocampal subfield CA3 becomes visible. $B$, Hippocampal slice culture of a double mutant shows the $\mathrm{C}$-shaped layer of pyramidal neurons but absence of a defined GC layer, even at 13 DIV. $C$, Timm staining of a hippocampal slice culture from a wild-type mouse (10 DIV) reveals a characteristic mossy fiber projection to the CA3 region. $D$, Absence of Timm staining and mossy fiber projections in a parallel culture that was prepared from a double knockout mouse. Scale bars: $A, 100 \mu \mathrm{m} ; B, 50 \mu \mathrm{m}$; $C, 70 \mu \mathrm{m}, D, 100 \mu \mathrm{m}$.
Figure 7. Abnormal associational projections of hilar mossy cells in the absence of an organized dentate gyrus. $A$, In wild-type entorhinohippocampal slice cultures, calretinin is a prominent marker of mossy cells in the hilus, labeling only axonal projections (white asterisks) that are confined to the appropriate termination zone, the inner molecular layer $(\mathrm{iml})$ of the DG. Note that the GC somata remain unlabeled. $B$, Cultures of double-mutant mice show a similar distribution of calretinin-positive mossy cells in the absence of a granule cell layer. However, stained axonal projections (associational fibers) are loosely distributed throughout the entire molecular layer (asterisks) and not restricted to the correct termination zone. $C, D$, are higher magnifications of the boxed areas in $A$ and $B$, respectively. $E C$, Entorhinal cortex; $h$, hilus; oml, outer molecular layer; iml, inner molecular layer.

wild-type and mutant mice (Fig. $5 A c, A d$ ). Most CA3 neurons displayed a regular action potential (AP) firing pattern (Connors and Gutnick, 1990) and large $(>1 \mathrm{nA})$ peak $\mathrm{Na}^{+}$currents (Fig. $5 B, C)$. A few CA3 pyramidal cells could fire only one AP that was
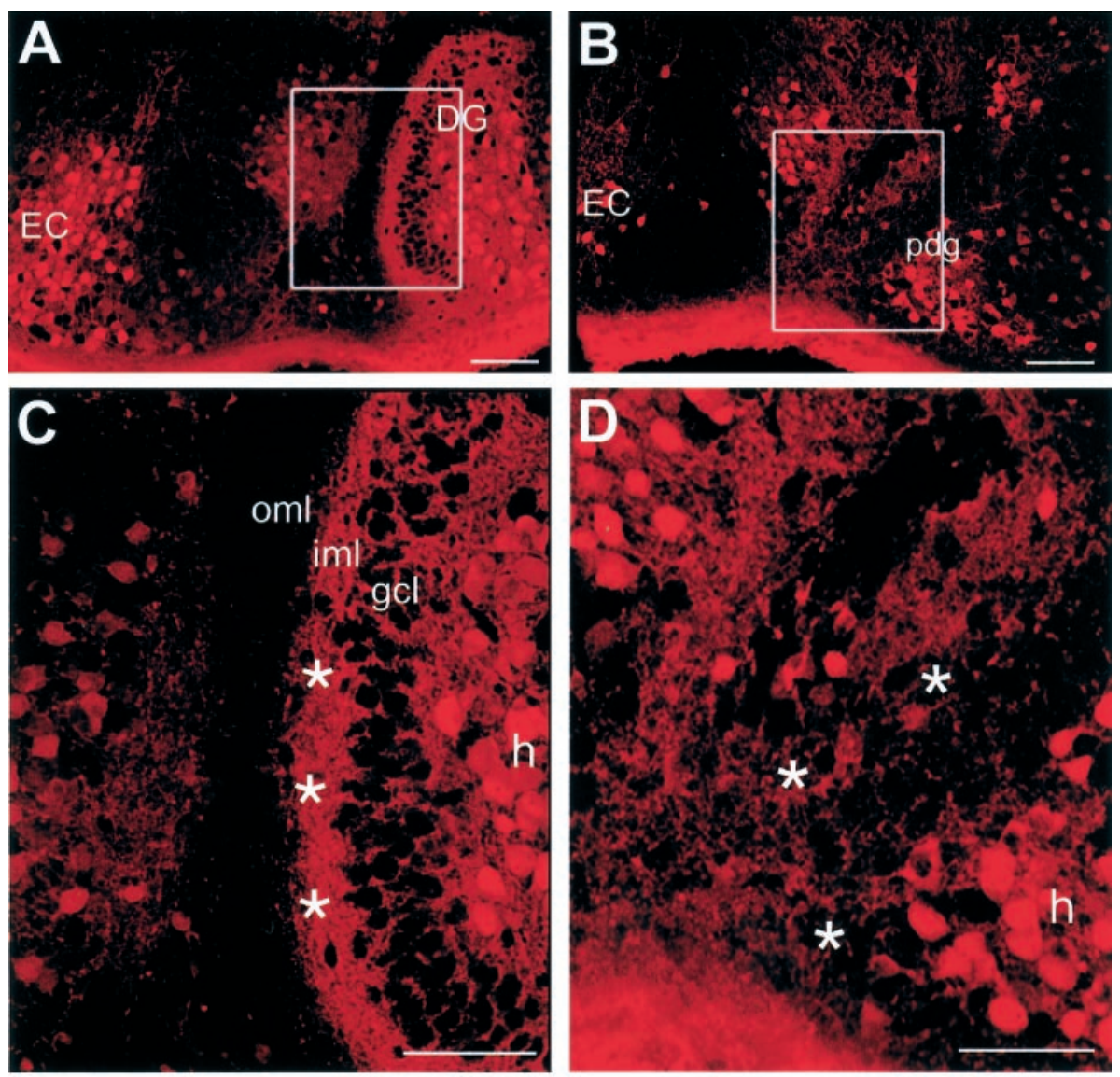

DKO not regenerative, and their fraction appeared larger in hippocampi of mutants. In all animals, interneurons located in the hilar and DG region were capable of firing AP. The firing pattern was characteristically "fast spiking" (Connors and Gutnick, 1990) 

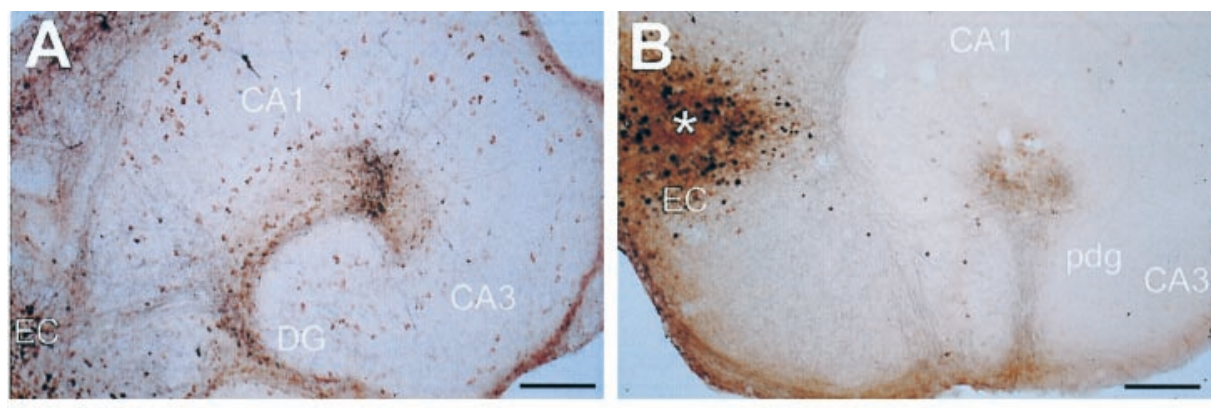

Figure 8. Abnormal distribution of reelinpositive Cajal-Retzius cells and entorhinal afferents in hippocampal/entorhinal cocultures. $A$, Low-power micrograph of a coculture derived from a wild-type mouse, showing reelinpositive Cajal-Retzius neurons in various hippocampal subfields. Biocytin-labeled entorhinal fibers occupy the expected termination zones in the hippocampus and the dentate gyrus. At higher magnification $(C)$ numerous browncolored, reelin-positive Cajal-Retzius cells colocalize in the termination zones of entorhinal fibers, the stratum lacunosum-moleculare $(\operatorname{slm})$ and the outer molecular layer $(\mathrm{oml})$ of the dentate gyrus. Arrowheads point to reelinpositive somata typically aligned along the hippocampal fissure. $B$, In cocultures derived from double-mutant mice, entorhinal axons innervate the hippocampus in a layered manner. High-power micrograph of the termination area of biocytin-labeled entorhinal afferents $(D)$ shows that the reelin-positive CajalRetzius cells have abnormally clustered and do not align along the hippocampal fissure. As in wild-type cultures, highest density of entorhinal fibers overlaps with the group of reelinimmunoreactive somatas. The final target cells, localized in the presumptive dentate gyrus, are largely ignored. Asterisks mark the site of biocytin application. $C A 1$, Regio superior; $C A 3$, regio inferior.

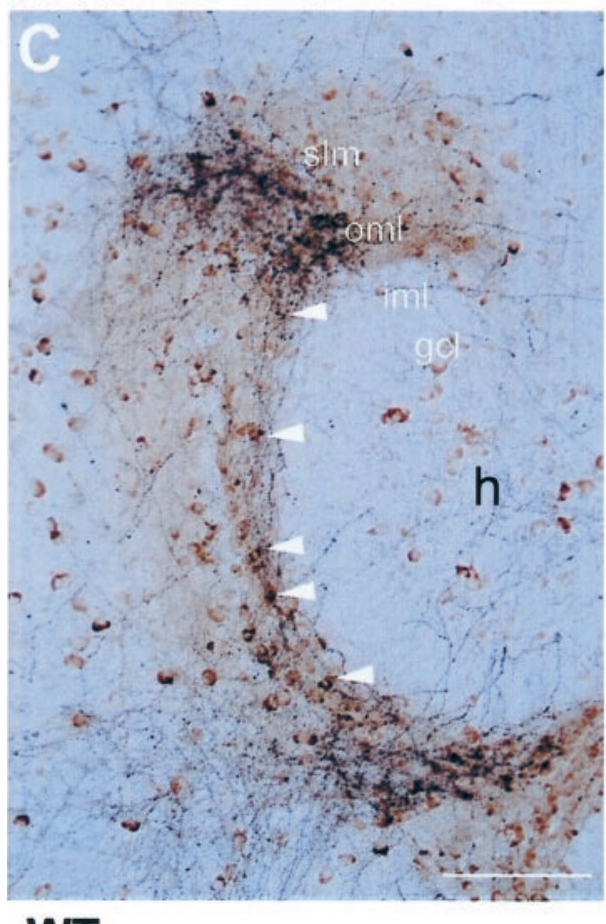

WT

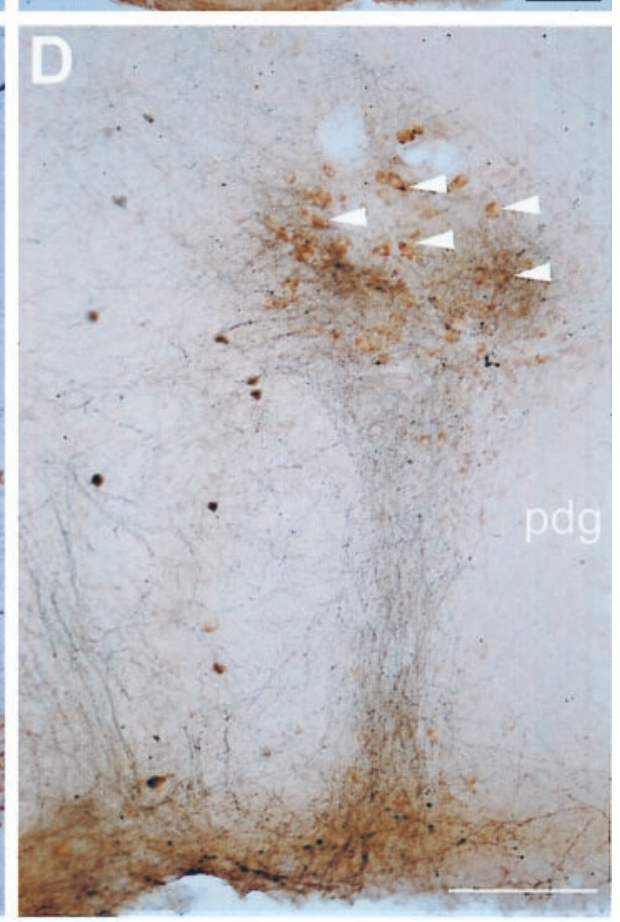

DKO with brief (0.5-1.0 msec) AP and pronounced afterhyperpolarizations. Both CA3 pyramidal cells and hilar interneurons received GABAergic synaptic input that was blocked with the $\mathrm{GABA}_{\mathrm{A}}$ receptor antagonist bicuculline $(20 \mu \mathrm{M})$ (data not shown). At P2, approximately half of the DG granule cells in normal brains were capable of firing one nonregenerative action potential and had peak $\mathrm{Na}^{+}$current exceeding $~ 500$ pA (Fig. $5 B, C$, bottom left panels). In some but not all GC that could fire APs, we observed a GABAergic synaptic input. In contrast, all presumptive GC of mutant mice had small $\mathrm{Na}^{+}$currents $(<500$ pA) and did not fire APs in response to a current pulse (Fig. 5B, $C$, bottom right panels). We found only three exceptions of cells (in $>30$ analyzed) with larger peak $\mathrm{Na}^{+}$currents and firing one nonregenerative AP, possibly undifferentiated interneurons. The absence of sodium currents in the majority of mutant cells was highly significant, also when normalized to their reduced cell surface (capacity), and was functionally confirmed by the lack of spike activity.

To overcome the early lethality of pancreatic failure in BETA2/ NeuroD -/- mice, we took advantage of a long-term organotypic culture system. Entorhinohippocampal complex slices and single hippocampal slices from newborn mice were cultivated for 10-14 DIV. Hippocampal pyramidal cell layers were found in all slices prepared from mice with either genotype. In contrast, a DG cell layer developed only in cultures from wild-type mice and $\mathrm{NEX}-/-{ }^{*} \mathrm{BETA} 2 / \mathrm{NeuroD}+/+$ or double-heterozygous mutants, but never in the absence of BETA2/NeuroD, even after 14 DIV (Fig. 6). Again, the difference between single and double mutants was quantitative rather than qualitative, as seen by histology before. Anterograde biocytin tracing of the DG in wildtype controls revealed labeled GC with typical apical dendritic arbor and mossy fiber projections into the CA3 field (Fig. 6A). In BETA2/NeuroD-deficient mice, biocytin labeling failed to label GC in the presumptive DG or axonal projections of these cells, even after 10 DIV (Fig. 6B). Normal hippocampal mossy fiber projections were heavily Timm silver-stained, but not in slice cultures of mice lacking BETA2/NeuroD (Fig. 6C,D).

Have presumptive GC in the mutants matured far enough to receive the proper input that defines the hippocampal circuitry in the wild-type? Calretinin immunocytochemistry was performed to label hilar interneurons (mossy cells) and their expected axonal projections to the inner molecular layer of the DG. Independent of the genotype, immunopositive mossy cells were normally clustered within the hilar region (Fig. 7). Whereas in wild-type slice cultures, calretinin-positive axons passed the unlabeled GC layer and arborized in their correct termination zone, i.e., the inner molecular layer of the DG (Fig. 7A, C), in cultured slices of double mutant mice, this layer-specific termination was completely lost. 
Immunostained fibers were in proximity to the mossy cells but spread from here throughout the entire molecular layer (Fig. $7 B, D)$. Similarly, when entorhinohippocampal complex slice cultures were biocytin-labeled, entorhinal cortical neurons projected normally into the hippocampal part of the coculture, indicating that in principle the navigation of cortical axons was not compromised. However, the final distribution of labeled entorhinal fibers differed remarkably in their termination zones. In cocultures from wild-type and heterozygous mice, entorhinal axons showed the typical distribution in the outer molecular layer of the dentate gyrus (Fig. $8 A, C$ ). In contrast, in slice cultures from mutants, the majority of labeled entorhinal axons were found diff usely distributed in the area of the presumptive DG (Fig. 8B,D).

Reelin-secreting Cajal-Retzius (CR) cells are known as the transient targets of entorhinal afferents in the hippocampus (del Rio et al., 1997). Different from granule cells, they do not express NeuroD (data not shown). Using reelin as a CR marker in the analysis of long-term slice cultures, we noticed a different distribution of CR cells in the mutants. Clusters of reelin-positive neurons were observed in or above the presumptive dentate gyrus (Fig. 8B,D), whereas in wild-type hippocampal cultures, reelincontaining somata showed a normal distribution in various hippocampal subfields and the characteristic alignment along the hippocampal fissure (Fig. 8A,C). In both wild-type and DKO cultures, the majority of labeled entorhinal fibers overlapped with the localization of reelin-positive CR cells. However, in the mutants the final cellular targets were not correctly innervated.

\section{DISCUSSION}

Taken together, the absence of BETA2/NeuroD causes a novel defect in the formation of the hippocampus, which is less compensated in mice double-deficient for NEX and BETA2/NeuroD. In fact, many cells in the visibly affected hilar region fail to express all three neuronal bHLH factors (including NDRF and NEX gene transcription), which is consistent with a localized breakdown of an autoregulatory bHLH system. Electrophysiological recordings allowed a single-cell analysis in the densely packed hilar region, and we obtained direct evidence for the presence of normal interneurons but a virtual lack of differentiated GC. Because both cell types are derived from one pool of early progenitors, it is possible that neuronal bHLH proteins participate also in a late step of lineage decision (Ahmad et al., 1998; Yan and Wang, 1998; Morrow et al., 1999). However, the abundance of immature cells that express some (but not all) neuronal differentiation markers demonstrates that one essential function of NEX, BETA2/NeuroD, and presumably also NDRF, is the control of terminal neuronal differentiation.

Abnormal behavior of entorhinal afferents and the loss of mossy fiber input of CA3 pyramidal neurons are clearly secondary defects. The fact that entorhinal projections fail to reach the final target region suggests that immature GC still lack the competence of receiving proper synaptic input. The role of Cajal-Retzius cells that serve as transient entorhinal targets and are present by immunostaining is under further investigation.

Although BETA2/NeuroD and NEX are expressed throughout the developing forebrain, most prominently in cortical structures (Schwab et al., 1998), the hippocampal defect is restricted to the DG and even the neighboring CA1-3 fields appear normal. We have corrected a previous assessment of NEX expression in the DG, after using the highly sensitive Cre-recombination system in double-transgenic mice. NEX expression is certainly low-level and only transient in the developing DG, but it suffices to explain why fewer GC neurons differentiate in the hilar region of BETA2/ NeuroD*NEX double mutant. However, the abnormal phenotype of individual mutant DG neurons, once arrested in differentiation, appears to be the same.

The reason for a restriction of the visible developmental defect to the hippocampal dentate gyrus (this study) and to cerebellar granule cells (Miyata et al., 1999) requires further investigation. In both regions, lack of BETA2/NeuroD causes extensive cell death. The lack of BETA2/NeuroD could affect the granule cells more than other areas, because presumptive GC have not terminally withdrawn from the cell cycle (similar to external granule cells of the cerebellum). Presumptive GC no longer express neurogenins and may require BETA2/NeuroD for the activation of downstream bHLH genes, neuronal structural genes, and a permanent cell cycle withdrawal. We note that in muscle development, MyoD induces the Cdk inhibitor p21, and thereby cell cycle arrest of myocytes, which is required, in turn, to allow terminal differentiation of myotubes (Lassar et al., 1994; Halevy et al., 1995). It is possible that the absence of BETA2/NeuroD alters a similar feedback loop and, specifically in the DG and cerebellum, a delicate balance between continued cell cycle progression and terminal neuronal differentiation. Unfortunately, it is difficult to compare our data with findings of reduced cell proliferation by Miyata et al. (1999), who used BrdU incorporation and analyzed the initial migratory cells from the ventricular zone.

In comparison to other mouse mutants with a defect of the hippocampal formation, the phenotype reported here is unique. The function of NEX and BETA2/NeuroD as terminal differentiation factors differs from previously described transcription factors in the brain, such as Oct-proteins, homeobox proteins, and neurogenic bHLH proteins, which collectively determine pattern formation, cell lineage commitment, and other early steps in the neuronal lineage. Mice that lack the transcription factor Emx2 have an early patterning defect of the dorsal forebrain, including the DG anlage, and consequently lack all DG cells (Pellegrini et al., 1996; Yoshida et al., 1997). A mutation of the LIM homeobox gene Lhx5 causes an early failure of hippocampal progenitor cells that fail to properly exit the cell cycle (Zhao et al., 1999). Neuronal ectopia and differentiation arrest are similar to that of GC lacking neuronal bHLH proteins but are not associated with apoptosis. Our ex vivo analysis in an organotypic culture system suggests that the hippocampal developmental arrest is stable over time and not a simple delay, which agrees with the report of Miyata et al. (1999).

Mouse mutants with hippocampal defects have become important tools for investigating the cellular basis of learning and memory. A CNS-specific inactivation of the BETA2/NeuroD gene, using NEX-Cre mice, should circumvent insulin-dependent lethality, developmental delays, and diabetic complications (Naya et al., 1997; Malecki et al., 1999). This will allow to also study the behavioral consequences in mice of lacking the major dentatohippocampal pathway.

\section{REFERENCES}

Adams JC (1981) Heavy metal intensification of DAB-based HRP reaction product. J Histochem Cytochem 29:775.

Ahmad I, Acharya HR, Rogers JA, Shibata A, Smithgall TE, Dooley CM (1998) The role of NeuroD as a differentiation factor in the mammalian retina. J Mol Neurosci 11:165-178.

Akagi K, Sandig V, Vooijs M, Van der Valk M, Giovannini M, Strauss M, Berns A (1997) Cre-mediated somatic site-specific recombination in mice. Nucleic Acids Res 25:1766-1773. 
Altman J, Bayer SA (1990a) Mosaic organization of the hippocampal neuroepithelium and the multiple germinal sources of dentate granule cells. J Comp Neurol 301:325-342.

Altman J, Bayer SA (1990b) Migration and distribution of two populations of hippocampal granule cell precursors during the perinatal and postnatal periods. J Comp Neurol 301:365-381.

Arnold HH, Winter B (1998) Muscle differentiation: more complexity to the network of myogenic regulators. Curr Opin Genet Dev 8:539-544.

Barami K, Iversen K, Furneaux H, Goldman SA (1995) Hu protein as an early marker of neuronal phenotypic differentiation by subependymal zone cells of the adult songbird forebrain. J Neurobiol 28:82-101.

Bartholomae A, Nave KA (1994) NEX-1: a novel brain-specific helixloop-helix protein with autoregulation and sustained expression in mature cortical neurons. Mech Dev 48:217-228.

Connors BW, Gutnick MJ (1990) Intrinsic firing patterns of diverse neocortical neurons. Trends Neurosci 13:99-104.

Deller T, Drakew A, Heimrich B, Forster E, Tielsch A, Frotscher M (1999) The hippocampus of the reeler mutant mouse: fiber segregation in area CA1 depends on the position of the postsynaptic target cells. Exp Neurol 156:254-267.

Frotscher M, Zafirov S, Heimrich B (1995) Development of identified neuronal types and of specific synaptic connections in slice cultures of rat hippocampus. Prog Neurobiol 45:143-164.

Gerlach C, Sakkab DY, Scholzen T, Dassler R, Alison MR, Gerdes J (1997) Ki-67 expression during rat liver regeneration after partial hepatectomy. Hepatology 26:573-578.

Halevy O, Novitch BG, Spicer DB, Skapek SX, Rhee J, Hannon GJ, Beach D, Lassar AB (1995) Correlation of terminal cell cycle arrest of skeletal muscle with induction of p21 by MyoD. Science 267:1018-1021.

Horikawa K, Armstrong WE (1988) A versatile means of intracellular labeling: injection of biocytin and its detection with avidin conjugates. J Neurosci Methods 25:1-11.

Kageyama R, Nakanishi S (1997) Helix-loop-helix factors in growth and differentiation of the vertebrate nervous system. Curr Opin Genet Dev $7: 659-665$.

Kume H, Maruyama K, Tomita T, Iwatsubo T, Saido TC, Obata K (1996) Molecular cloning of a novel basic helix-loop-helix protein from the rat brain. Biochem Biophys Res Commun 219:526-530.

Lassar AB, Skapek SX, Novitch B (1994) Regulatory mechanisms that coordinate skeletal muscle differentiation and cell cycle withdrawal. Curr Opin Cell Biol 6:788-794.

Lee JE (1997) Basic helix-loop-helix genes in neural development. Curr Opin Neurobiol 7:13-20.

Lee JE, Hollenberg SM, Snider L, Turner DL, Lipnick N, Weintraub H (1995) Conversion of Xenopus ectoderm into neurons by NeuroD, a basic helix-loop-helix protein. Science 268:836-844.

Ma Q, Kintner C, Anderson DJ (1996) Identification of neurogenin, a vertebrate neuronal determination gene. Cell 87:43-52.

Malecki MT, Jhala US, Antonellis A, Fields L, Doria A, Orban T, Saad M, Warram JH, Montminy M, Krolewski AS (1999) Mutations in NeuroD1 are associated with the development of type 2 diabetes mellitus. Nat Genet 23:323-328.

McCormick MB, Tamimi RM, Snider L, Asakura A, Bergstrom D, Tapscott SJ (1996) NeuroD2 and neuroD3: distinct expression patterns and transcriptional activation potentials within the neuroD gene family. Mol Cell Biol 16:5792-800.
Miyata T, Maeda T, Lee J (1999) NeuroD is required for differentiation of the granule cells in the cerebellum and hippocampus. Genes Dev 13:1647-1652.

Morrow EM, Furukawa T, Lee JE, Cepko CL (1999) NeuroD regulates multiple functions in the developing neural retina in rodent. Development 126:23-36.

Naya FJ, Stellrecht CM, Tsai MJ (1995) Tissue-specific regulation of the insulin gene by a novel basic helix-loop-helix transcription factor. Genes Dev 9:1009-1019.

Naya FJ, Huang HP, Qiu Y, Mutoh H, DeMayo FJ, Leiter AB, Tsai MJ (1997) Diabetes, defective pancreatic morphogenesis, and abnormal enteroendocrine differentiation in BETA2/neuroD-deficient mice. Genes Dev 11:2323-2334.

Pellegrini M, Mansouri A, Simeone A, Boncinelli E, Gruss P (1996) Dentate gyrus formation requires Emx2. Development 122:3893-3898.

Schwab MH, Druffel-Augustin S, Gass P, Jung M, Klugmann M, Bartholomae A, Rossner MJ, Nave KA (1998) Neuronal basic helix-loophelix proteins (NEX, neuroD, NDRF): spatiotemporal expression and targeted disruption of the NEX gene in transgenic mice. J Neurosci 18:1408-1418.

Schwegler H, Heimrich B, Keller F, Renner P, Crusio WE (1988) Strainspecific development of the mossy fiber system in organotypic cultures of the mouse hippocampus. Neurosci Lett 87:7-10.

Shimizu C, Akazawa C, Nakanishi S, Kageyama RC (1995) MATH-2, a mammalian helix-loop-helix factor structurally related to the product of Drosophila proneural gene atonal, is specifically expressed in the nervous system. Eur J Biochem 229:239-248.

Sommer L, Ma Q, Anderson DJ (1996) Neurogenins, a novel family of atonal-related bHLH transcription factors, are putative mammalian neuronal determination genes that reveal progenitor cell heterogeneity in the developing CNS and PNS. Mol Cell Neurosci 8:221-241.

Stanfield BB, Cowan WM (1979) The development of the hippocampus and dentate gyrus in normal and reeler mice. J Comp Neurol 185:423-459.

Stoppini L, Buchs PA, Muller D (1991) A simple method for organotypic cultures of nervous tissue. J Neurosci Methods 37:173-182.

Thayer MJ, Tapscott SJ, Davis RL, Wright WE, Lassar AB, Weintraub H (1989) Positive autoregulation of the myogenic determination gene MyoD1. Cell 58:241-248.

Yan RT, Wang SZ (1998) neuroD induces photoreceptor cell overproduction in vivo and de novo generation in vitro. J Neurobiol 36:485-96.

Yasunami M, Suzuki K, Maruyama H, Kawakami H, Nagai Y, Hagiwara M, Ohkubo H (1996) Molecular cloning and characterization of a cDNA encoding a novel basic helix-loop-helix protein structurally related to Neuro-D/BHF1. Biochem Biophys Res Commun 220:754-758.

Yoon YS, Noma T, Yamashiro Y, Ito H, Nakazawa A (1998) Molecular cloning and characterization of the gene encoding human NeuroD. Neurosci Lett 251:17-20.

Yoshida M, Suda Y, Matsuo I, Miyamoto N, Takeda N, Kuratani S, Aizawa S (1997) Emx1 and Emx2 functions in development of dorsal telencephalon. Development 124:101-111.

Zhao Y, Sheng HZ, Amini R, Grinberg A, Lee E, Huang S, Taira M, Westphal H (1999) Control of hippocampal morphogenesis and neuronal differentiation by the LIM homeobox gene Lhx5. Science 284: $1155-1158$. 